\title{
AKRUAL
}

Jurnal Akuntansi

http://journal.unesa.ac.id/php.index/aj

\section{ANALISA FAKTOR RASIO LIKUIDITAS , RASIO AKTIVITAS, RASIO PROFITABILITAS DAN RASIO COVERAGE \\ DALAM PENANAMAN MODAL ASING (PMA) \\ (STUDI EMPIRIS PADA PERUSAHAAN SEKTOR TRADE, SERVICE DAN INVESTMENT )}

\author{
Ade Manggala Hardianto \\ Mahasiswa S3 Ilmu Akuntansi Universitas Airlangga \\ ade.manggala.hardianto-2016@feb.unair.ac.id
}

\begin{abstract}
Abstrak
Istilah multinasional menunjukan pada perusahaan penanaman modal asing (PMA), sebagai anak perusahaan yang berafiliasi bisnis dengan dengan perusahaan induk yang berkedudukan kantor pusat diluar negeri. Sedangkan, perusahaan domestik adalah perusahaan penanaman modal dalam negeri, kantor pusat yang berkedudukan di Indonesia. Analisa Faktor Yang Berkorelasi Dalam Penanaman Modal Asing: Matrik 1 Current Ratio $(0,599)$, Return On Asset (0,931), Retrun On Equity (0,77), Net Profit Margin (0,601). Matrik 2 1) Earning Per Share (EPS) (0,993) dan Dan Times Interest Earned $(0,926)$. Matrik 3 1) cash ratio $(0,729)$ dan 2) Account Receivable Turnover $(0,877)$. Matrik 4 Inventory Turnover, (0,982), Matrik 5 Total Asset Turn Over (TATO) sebesar 0,545. Perusahaan PMA dengan profitabiltas dan likuiditas yang tinggi terdapat 1 (satu) perusahaan yaitu United tracktor hal ini ditunjukan dengan nilai earning per share (EPS) sebesar 1.440 per lembar saham. EPS yang tinggi akan menarik minat para Investor untuk menanamkan dananya lebih banyak, dan keuntungan perusahaan adalah mendapatkan dana segar untuk lebih meningkatkan produktivitas perusahaan. Dan likuiditas sebesar 206\% pada Current rasio, $158 \%$ pada Quick test ratio, dan cash ratio 62\%.
\end{abstract}

Kata Kunci: PMA, Current Ratio, Return On Asset, Return On Equity, Net Profit Margin, Earning Per Share, Times Interest Earned

\section{Pendahuluan}

Pasar modal mempunyai peranan yang cukup besar sebagai salah satu sumber pembiayaan bagi dunia usaha, disisi lain juga merupakan tempat investasi bagi masyarakat termasuk pemodal kecil dan menengah. Pasar modal memiliki peran penting bagi perekonomian suatu negara yang sedang berkembang seperti bangsa Indonesia, terutama dalam proses alokasi dana dari pihak yang memiliki surplus dana (investor) kepada pihak yang memerlukan dana (perusahaan). Kehadiran pasar modal di Indonesia 
semakin memberikan kesempatan luas bagi perusahaan untuk memperoleh dana dari masyarakat.

Tujuan utama perusahaan yang telah go public adalah meningkatkan kemakmuran pemilik atau para pemegang saham melalui peningkatan nilai perusahaan (Salvatore, 2005). Nilai perusahaan adalah sangat penting karena dengan nilai perusahaan yang Tinggi akan diikuti oleh Tingginya kemakmuran pemegang saham (Bringham and Gapenski, 2006). Semakin Tinggi harga saham semakin Tinggi nilai perusahaan.

Kondisi fundamental perusahaan mengacu pada informasi tentang kinerja perusahaan, resiko, ukuran prospek perusahaan maupun masalah kepemilikan perusahaan tersebut. Faktor teknis (teknikal) merupakan faktor yang menggambarkan perkembangan perdagangan saham di lantai bursa seperti harga perdana, fluktuasi saham, jumlah harga saham, dan lain-lain. Dan sentimen pasar merupakan faktor-faktor lain yang tidak dapat diukur secara kuantitatif seperti situasi politik, prilaku investor, kejadian luar biasa misalnya bencana alam dan lain-lain. Dalam menilai kinerja suatu perusahaan ditinjau dari aspek keuangan, investor harus melakukan analisis terhadap laporan keuangan perusahaan emiten, sehingga terlihat saham perusahaan layak atau tidak untuk dibeli.

Penelitian mengenai hubungan struktur kepemilikan saham oleh pihak manajemen dengan struktur modal perusahaan telah dilakukan, seperti studi Agrawal dan Kneober (1996), Mao (2003), Chen et all (2006) menunjukan cukup bukti bahwa kepemilikan saham oleh pihak manajemen berkorelasi positif dengan rasio hutang perusahaan. Namun Chen dan strange (2006) demikian pula dengan jensen et all (1992), Moh'h et all (1998), bahwa kepemilikan saham oleh pihak manajemen memiliki hubungan negatif dengan struktur modal. Jensen (1986) menyatakan, manajer dan pemegang saham selalu berbeda kepentingan yang dikenal dengan konflik keagenan. Lebih lanjut, dinyatakan bahwa salah satu masalah antara manajer dan pemegang saham adalah pemegang saham lebih menyukai dividen daripada diinvestasikan kembali, sementara sebaliknya bagai manajer. Namun demikian, ketika pihak manajemen dilibatkan dalam bentuk insider ownership, maka kepentingan pemegang saham akan sesuai dengan kepentingan manajer. Karena para manajer juga akan akan memperoleh tingkat pengembalian atas kepemilikannya dalam bentuk dividen, sehingga konflik yang terjadi dapat dikurangi. 
Tabel 1

Rasio Likuiditas Dan Profitabilitas Penanaman Modal Asing

\begin{tabular}{|c|c|c|c|c|c|c|c|c|}
\hline \multirow{2}{*}{ NO } & \multirow{2}{*}{ Nama Perusahaan } & \multicolumn{3}{|c|}{ LIKUIDTAS } & \multicolumn{4}{|c|}{ PROFITABILITAS } \\
\hline & & $\mathbf{C R}$ & QTR & $\mathbf{C R}$ & ROA & ROE & NPM & EPS \\
\hline \multirow[t]{2}{*}{1} & Sigmagold Inti Perkasa Tbk. *) & 2,69 & 2,40 & 0,06 & 0,22 & 0,25 & 2,08 & 1 \\
\hline & Ancora Indonesia Resources & & & & & - & & \\
\hline 2 & Tbk. & 0,67 & 0,52 & 0,14 & $-3,05$ & 19,88 & $-4,02$ & -39 \\
\hline 3 & Evergreen Invesco Tbk. [S] *) & 0,89 & 0,58 & 0,06 & 0,04 & 0,05 & 0,19 & 0 \\
\hline \multirow[t]{2}{*}{4} & FKS Multi Agro Tbk. [S] & 1,19 & 0,44 & 0,09 & 3,54 & 13,66 & 0,57 & 185 \\
\hline & Millennium & & & & & & & \\
\hline 5 & International Tbk. [S] & 1,30 & 0,80 & 0,16 & 1,31 & 5,68 & 0,48 & 10 \\
\hline 6 & Modern Internasional Tbk. [S] & 1,44 & 1,01 & 0,06 & 1,66 & 2,94 & 2,76 & 9 \\
\hline \multirow[t]{2}{*}{7} & United Tractors Tbk. [S] & 2,06 & 1,58 & 0,62 & 8,17 & 12,76 & 9,26 & 1.440 \\
\hline & Wicaksana Overseas & & & & & & & \\
\hline 8 & International Tbk. [S] & 2,03 & 1,39 & 0,19 & 19,25 & 31,76 & 7,80 & 31 \\
\hline \multirow[t]{2}{*}{9} & $\begin{array}{l}\text { Ace Hardware Indonesia Tbk. } \\
{[\mathrm{S}]}\end{array}$ & 5,09 & 2,05 & 0,92 & 18,62 & 23,24 & 12,09 & 32 \\
\hline & Sona Topas Tourism Industry & & & & & & & \\
\hline \multirow[t]{2}{*}{10} & Tbk. [S] & 3,20 & 2,09 & 1,79 & 9,93 & 16,48 & 8,88 & 327 \\
\hline & Tiphone Mobile Indonesia Tbk. & & & & & & & \\
\hline 11 & {$[\mathrm{~S}]$} & 1,80 & 1,42 & 0,26 & 6,08 & 12,20 & 2,09 & 43 \\
\hline \multirow[t]{2}{*}{12} & Trikomsel Oke Tbk. & 2,59 & 1,99 & 0,19 & 3,66 & 13,96 & 3,08 & 66 \\
\hline & Indonesian Paradise Property & & & & & & & \\
\hline \multirow[t]{2}{*}{13} & Tbk. $[\mathrm{S}]$ & 1,87 & 1,84 & 1,30 & 3,39 & 6,23 & 12,76 & 10 \\
\hline & Island Concepts Indonesia Tbk. & & & & & & & \\
\hline \multirow[t]{2}{*}{14} & $*)$ & 1,99 & 1,48 & 0,81 & 1,93 & 3,49 & 3,14 & 1 \\
\hline & Multipolar Technology Tbk. & & & & & & & \\
\hline 15 & {$[\mathrm{~S}]$} & 1,28 & 1,05 & 0,44 & 3,90 & 11,13 & 3,45 & 38 \\
\hline 16 & Global Mediacom Tbk. [S] & 4,17 & 3,38 & 0,58 & 4,71 & 7,52 & 11,21 & 50 \\
\hline \multirow[t]{2}{*}{17} & MNC Investama Tbk. & 1,66 & 1,47 & 0,34 & 2,36 & 4,97 & 9,00 & 5 \\
\hline & Rata-rata & 2,11 & 1,50 & 0,47 & 5,04 & 8,61 & 4,99 & 129,88 \\
\hline
\end{tabular}

( data diolah sendiri) 


\section{LANDASAN TEORITIS}

Menurut Gitman (2003:591) Profitability is the relationship between revenues and cost generated by using thr firm's asset both current and fixed in productive activities. Keuntungan merupakan hubungan anatar pendapatan dan biaya secara keseluruhan , karena penggunaaan atas aset lancar mapun aset tetap dalam menjalankan kegiatan produktivitas.

Laba bersih (net income) merupakan ukuran pokok keseluruhan keberhasilan perusahaan laba dapat mempengaruhi kemampuan perusahaan untuk mendapatkan pinjaman dan pendanaan ekuitas, posisi likuiditas perusahaan dan kemampuan perusahaan untuk berubah. Jumlah keuntungan yang diperoleh secara teratur serta kecenderungan atau trend keuntungan yang meningkat merupakan faktor yang sangat penting yang perlu mendapat perhatian penganalisa dalam menilai profitabilitas suatu perusahaan.

Menurut Hanafi dan Halim (2003;27), Return On Asset merupakan rasio keuangan perusahaan yang berhubungan dengan profitabilitas, mengukur kemampuan perusahaan menghasilkan keuntungan atau laba pada tingkat pendapatan, aset dan modal saham tertentu. Dengan mengetahui ROA, kita dapat menilai apakah perusahaan telah efesien dalam menggunakan aktivanya dalam kegiatan operasi untuk menghasilkan keuntungan.

Menurut Lestari dan Sugiharto (2007:196) angka ROA dikatakan baik apabila > 2\%.Return On Equity (ROE) adalah rasio yang menunjukan kemampuan perusahaan dalam menghasilkan laba bersih dengan menggunakan modal sendiri dan menghasilkan laba bersih yang tersedia abgi pemilik dan investor. ROE sangat tergantung pada besar dan kecilnya perusahaan, misalnya untuk perusahaan kecil tentu memiliki modal yang relativ kecil, sehingga ROE yang dihasilkannya pun kecil.

Sawir (2008:14) mengatakan bahwa rasio ini juga disebut dengan rasio penutupan ( Coverage Ratio) yang mengukur kemampuan pemenuhan kewajiban bunga tahunan dengan laba operasi (EBIT) dan mengukur sejauh mana laba operasi boleh diturunkan tanpa menyebabkan kegagalan dari pemenuhan kewajiban membayar bunga pinjaman

\section{Metode penelitian}

\section{Desain Penelitian}

Penelitian ini bertujuan untuk menguji dan menganalisis faktor likuiditas, aktivity rasio, profitabilitas raso dan coverage rasio Sesuai dengan tujuan penelitian, maka jenis 
penelitian yang digunakan dalam penelitian ini adalah penelitian verifikatif (verificative research) atau penelitian pengujian korelasi antar faktor yang berkaitan antar variabel.

\section{Populasi dan Sampel Penelitian}

Peneliti mengambil populasi pada Bursa Efek Indonesia, dengan responden adalah perusahaan manufaktur sektor trade, service dan investment yang menyajikan laporan keuangan tahun 2014. Dalam penelitian ini menggunakan metode nonprobability sampling dengan teknik purposive sampling yaitu sampel yang dipilih berdasarkan kategori perusahaan yang menyajikan laporan keuangan dengan lengkap

\section{Operasional Variabel}

Operasioal variabel bertujuan untuk memberikan pedoman, arahan, atau petunjuk pada pelaksanaan pengukuran suatu variabel agar dapat dicapai pengukuran yang objektif. Sesuai dengan judul penelitian ini, maka ditentukan variabelnya sebagai berikut: Likuiditas yaitu current rasio, quick tes ratio, cash rasio, Activity ratio yaitu, account receivable turnover, inventory turnover dan asset turnover, profitability ratio yaitu Return On Asset, Return On Equity, Net profit Margin dan Earning Per share. Coverage ratio yaitu, debt to equity, total liability to taotal aset, dan times interest earned

\section{Metode Analisa Data}

Untuk mengetahui bagaimana hubungan antar variabel yaitu likuiditas ratio, activity ratio, profitabilitas ratio dan coverage ratio maka dilakukan analisis data dengan menggunakan analisa statistik. Metode yang digunakan dengan menggunakan korelasi hubungan faktor ( corellational factor ) yaitu bagaimana mencari korelasional faktor 13 variabel yang diteliti dan memiliki keterkaitan dan menginterpretasikan komponen faktor dalam matrik.

Tabel 2

\section{Pedoman Untuk Memberikan Interpretasi Koefisien Korelasi}

\begin{tabular}{ll}
\hline \multicolumn{1}{c}{ Interval Koefisien } & \multicolumn{1}{c}{ Tingkat Hubungan } \\
\hline $0,00-0,199$ & Sangat rendah \\
$0,20-0,0399$ & Rendah \\
$0,40-0,599$ & Sedang \\
$0,60-0,799$ & Kuat \\
$0,80-1,00$ & Sangat kuat \\
\hline
\end{tabular}




\section{Hasil Dan Pembahasan}

\section{Analisa Faktor Yang Berkorelasi Dalam Penanaman Modal Dalam Asing}

Berdasarkan hasil olah data dengan menggunakan tool minitab, korelasi yang akan dijelaskan terdiri dari 13 faktor yaitu 1) Current Rasio ( Cr ) 2) Quick Test Rasio (Qr) 3. Cash Ratio (Cr) 4) Activity Ratio Turn Over (Arto ) 5) Inventori Turnover (Ito) 6) Asset Turnover( Ato) 7) Return On Asset (ROA)8) Return On Equity ( Roe ) 9) Net Profit Margin (Npm) 10) Earning Per Share (Eps) 11) Debt To Equityrasio (Der) 12) Total Liability To Total Aset (Dar) 13) Times Interest Earned ( Tie)

\section{MATRIK 1}

Hasil analisa dalam matrik pertama, alat analisa keuangan Current Ratio $(0,599)$, Return On Asset (0,931), Retrun On Equity (0,77), Net Profit Margin (0,601). Hasil olah pada matrik pertama menunjuka hubungan positif semua komponen, dalam analisa ini Net profit margin (NPM) menunjukan kemampuan perusahaan untuk menghasilkan margin tertentu sehingga memotivasi para investor untuk menanamkan modalnya diperusahaan. Menurut Gitman (2003:591) Profitability is the relationship between revenues and cost generated by using thr firm's asset both current and fixed in productive activities. Keuntungan merupakan hubungan anatar pendapatan dan biaya secara keseluruhan , karena penggunaaan atas aset lancar mapun aset tetap dalam menjalankan kegiatan produktivitas.

Laba bersih (net income) merupakan ukuran pokok keseluruhan keberhasilan perusahaan laba dapat mempengaruhi kemampuan perusahaan untuk mendapatkan pinjaman dan pendanaan ekuitas, posisi likuiditas perusahaan dan kemampuan perusahaan untuk berubah. Jumlah keuntungan yang diperoleh secara teratur serta kecenderungan atau trend keuntungan yang meningkat merupakan faktor yang sangat penting yang perlu mendapat perhatian penganalisa dalam menilai profitabilitas suatu perusahaan.

Namun kemampuan perusahaan untuk meningkatkan pendapatan tidak terlepas dari Hal lain yang saling berhubungan yaitu; 1) Current Ratio, menunjukan bahwa pengelolaan rasio hutang dapat di kelola denga jumlah aset yang tersedia pada aktiva lancar dan aktiva tetap, bila rasio meningkat menunjukan bahwa kemampuan perusahaan bila terjadi distress atau kebangkrutan perusahaan dapat membayar utangnya denga seluruh aktiva yang dimiliki oleh perusahaan . 2) Return On Asset (ROA), menurut Hanafi dan Halim (2003;27), Return On Asset merupakan rasio keuangan perusahaan yang berhubungan dengan profitabilitas, mengukur kemampuan perusahaan 
menghasilkan keuntungan atau laba pada tingkat pendapatan, aset dan modal saham tertentu. Dengan mengetahui ROA, kita dapat menilai apakah perusahaan telah efesien dalam menggunakan aktivanya dalam kegiatan operasi untuk menghasilkan keuntungan. Menurut Lestari dan Sugiharto (2007:196) angka ROA dikatakan baik apabila > 2\%. 2) Return On Equity (ROE) adalah rasio yang menunjukan kemampuan perusahaan dalam menghasilkan laba bersih dengan menggunakan modal sendiri dan menghasilkan laba bersih yang tersedia abgi pemilik dan investor. ROE sangat tergantung pada besar dan kecilnya perusahaan, misalnya untuk perusahaan kecil tentu memiliki modal yang relativ kecil, sehingga ROE yang dihasilkannya pun kecil.

Tabel 3

Interpretasi korelasi matrik 1

\begin{tabular}{llll}
\hline No & Variabel & Nilai & \multicolumn{1}{c}{ Interpretasi } \\
\hline 1 & Current Ratio & 0,599 & Sedang \\
2 & Return On Asset & 0,931 & Sangat kuat \\
3 & Retrun On Equity & 0,77 & Kuat \\
4 & Net Profit Margin & 0,601 & Kuat \\
\hline
\end{tabular}

\section{MATRIK 2}

Hasil analisa dalam matrik kedua yaitu, 1) Earning Per Share (EPS) (0,993) dan Dan Times Interest Earned (0,926). Dalam lingkaran keuangan alat ukur yang paling sering digunakan adalah Earning Per Share (EPS). Angka yang ditunjukan dari EPS inilah yang sering dipublikasikan mengenai performance perusahaan yang menjual sahamnya kepada masyarakat luas (go public). karena investor maupun calon investor berpandangan bahwa EPS mengandung informasi yang penting untuk memprediksi mengenai besarnya dividen persaham dikemudian hari dan tingkat pengembalian saham dikemudian hari. Serta EPS juga relevan untuk menilai efektifitas manajemen dan kebijakan pembagian dividen.

Dalam PSAK No 56 mengharuskan perusahaan untuk meghitung EPS ilusian, karena saham biasa memiliki efek dilusi artinya perusahaan mempertimbangkan semua efek berpotensi saham biasa yang beredar dalam suatu periode, seperti efek utang (debt securities) warrant atau opsi saham, kebijakan kepegawaian, dan saham saham yang akan 
diternitkan saat terpenuhinya kondisi-kondisi tertentu, seperti kontrak pembelian aktiva atau usaha lainnya. Besarnya EPS dilusi dapat diketahui dari informasi laporan keuangan perusahaan, meskipun ada beberapa perusahaan yang tidak mencantumkan besarnya EPs dilusi. Sedangkan Times Interest Earned merupakan perbandingan laba bersih sebelum bunga dan pajak dengan beban bunga dan merupakan rasio yang mencerminkan besarnya jaminan keuangan untuk mebayar beban utang jangka panjang. Sawir (2008:14) mengatakan bahwa rasio ini juga disebut dengan rasio penutupan (Coverage Ratio) yang mengukur kemampuan pemenuhan kewajiban bunga tahunan dengan laba operasi (EBIT) dan mengukur sejauh mana laba operasi boleh diturunkan tanpa menyebabkan kegagalan dari pemenuhan kewajiban membayar bunga pinjaman.

Tabel 4

Interpretasi korelasi matrik2

\begin{tabular}{llll}
\hline No & Variabel & Nilai & Interpretasi \\
\hline 1 & Earning Per Share & 0,993 & Sangat kuat \\
2 & Times Interest Earned & 0,926 & Sangat kuat \\
\hline
\end{tabular}

\section{MATRIK 3}

Hasil analisa dalam matrik ketiga yaitu, 1) cash ratio ( 0,729) dan 2) Account Receivable Turnover $(0,877)$.Dalam matrik ini korelasi menunjukan angka positif artinya pengukuran likuiditas atau kemampuan perusahaan untuk membayar kewajiban jangka pendek dapat terpenuhi secara kas. Rasio kas, merupakan ratio yang paling likuid dibandingkan dengan dengan ratio likuiditas lainnya. Tingkat likuiditas kas pada harta perusahaan merupakan komponen yang sangat krusial, baik kas ditangan atau kas dalam giro. Semakin Tinggi tingkat rasio pada kas menunjukan pada kemampuan perusahaan dalam memabayar kewajiban jangka pendek juga semakin besar, hal ini akan menarik kepercayaa para kreditor dan investor untuk menanamkan dananya lebih banyak lagi.

Namun bila rasio ini Rendah, maka perusahaan perlu memberikan informasi yang lebih rinci untuk menjelaskan Rendahnya kinerja dibanding perusahaan yang mempunyai likuiditas yang tinnggi. Faktor yang mempengaruhi penerimaan kas adalah ratio perputaran penjualan ( Account Receivable Turnover), merupakan penjualan secara kredit dimana penerimaan secara kas ditentukan pada periode pembayaran, dan umur piutang menjadi masalah penting bagi perusahaan. Piutang yang terlalu lama, maka akan mengakibatkan perputaran kas tidak lancar bahkan akan menimbulkan perusahaan 
bangkrut, karena ketidak sedianya dana kas pada perusahaan. Analisa umur piutang menggambarkan kadar kemampuan piutang itu akan tertagih atau tidak. Semakin lama umur piutang maka kemungkinan besar piutang tidak akan tertagih.

Tabel 5

Interpretasi matrik 3

\begin{tabular}{llll}
\hline No & Variabel & Nilai & Interpretasi \\
\hline 1 & Cash Ratio & 0,729 & Kuat \\
2 & Account receivable turnover & 0,877 & Sangat kuat \\
\hline
\end{tabular}

\section{MATRIK 4}

Hasil pada matrik ke empat adalah Inventory Turnover, $(0,982)$, adalah perputaran persediaan yang dimiliki oleh perusahan dalam satu periode. Inventory Turnover tidak berkaitan dengan variabel lain disebabkan karena perputaran persediaan menghitung lamanya waktu persediaan akan sampai ke gudang dan untuk menentukan besarnya jumlah minimal persediaan barang tersedia dalam gudang. Persediaan barang dapat diperoleh secara impor, artinya perjalanan waktu sampai barang pada gudang dalam setahun sehingga menghasilkan lama perjalanan. Inventory Turnover juga menghitung jumlah perputaran dalam setahun, bila dalam setahun Inventory Turnover Tinggi, maka perusahaan harus lebih memperketat pengawasan pada persediaan awal dan akhir karena pembelian barang membutuhkan dana yang besar dan harus sesuai dengan penggunaan persedaiaan dalam menjalankan produktivitas perusahaan. Interpretasi korelasi pada Inventory Turnover sangat kuatlah kuat mengingat faktor utama produktivitas perusahaan dilihat dari ketersediaan barang untuk diolah.

\section{MATRIK 5}

Hasil analisa dalam matrik kelima adalah Total Asset Turn Over (TATO) sebesar 0,545 sedang, merupakan rasio yang menggambarkan perputaran aktiva dikur dari volume volume penjualan . jadi semakin besar rasio ini semakin baik yang berarti bahwa aktiva dapat lebih cepat berputar dan meraih laba dan menunjukan semakin efesien penggunaan keseluruhan aktiva dalam menghasilkan penjualan. Bagi perusahan manufaktur persediaan persediaan barang memiliki peran yang sangat penting, karena persediaan untuk mendukung kegiatan produksi. Namun sebaliknya bagi perusahaan Jasa pelayanan , perusahaan tidak akan berfokus pada persediaan akan tetapi pada aktiva untuk 
memberikan pelayanan yang optimal apalagi bilamana kondisi ekonomi stabil . kondisi ekonomi yang baik akan mempengaruhi tingkat pendapatan, dan perusahaan akan lebih mendapatkan laba yang Tinggi dari keadaan seperti ini

\section{Interpretasi Profitabiltas Dan Likuiditas Perusahaan}

Dalam hal ini, istilah multinasional menunjukan pada perusahaan penanaman modal asing (PMA), sebagai anak perusahaan yang berafiliasi bisnis dengan dengan perusahaan induk yang berkedudukan kantor pusat diluar negeri. Sedangkan, perusahaan domestik adalah perusahaan penanaman modal dalam negeri , kantor pusat yang berkedudukan di Indonesia. Tujuan dari interpretasi ini adalah untuk memberikan gambaran kepada para kreditor dan investor yang akan memberikan pinjaman atau penanaman modal pada perusahaan. Hal ini disebabkan kepentingan stakeholders, adalah mendapatkan dividen atas dana yang ditanamkan perusahaan. PMA yang dianalisa pada sektor Trade, Service Dan Investment. Yakni perusahaan dagang, perusahaan pelayanan dan investasi, adapun data yang diolah adalah data tahun 2014

Tabel 7

Hasil dan interpreasi profitabilitas dan liuiditas

\begin{tabular}{llcc}
\hline No & Nama & Profitabilitas & Likuiditas \\
\hline 1 & Sigmagold Inti Perkasa Tbk & Rendah & Rendah \\
2 & Ancora Indonesia Resources Tbk & Rendah & Rendah \\
3 & Evergreen Invesco Tbk. & Rendah & Rendah \\
4 & FKS Multi Agro Tbk & Rendah & Tinggi \\
5 & Millennium Pharmacon International Tbk & Rendah & Rendah \\
6 & Modern Internasional Tbk & Rendah & Rendah \\
7 & United Tractors Tbk & Tinggi & Tinggi \\
8 & Wicaksana Overseas International Tbk & Tinggi & Rendah \\
9 & Ace Hardware Indonesia Tbk. & Tinggi & Rendah \\
10 & Sona Topas Tourism Industry Tbk & Rendah & Tinggi \\
11 & Tiphone Mobile Indonesia Tbk. & Rendah & Rendah \\
12 & Trikomsel Oke Tbk & Rendah & Rendah \\
\hline
\end{tabular}




\begin{tabular}{clcc}
13 & Indonesian Paradise Property Tbk. & Rendah & Rendah \\
14 & Island Concepts Indonesia Tbk & Rendah & Rendah \\
15 & Multipolar Technology Tbk & Rendah & Rendah \\
16 & Global Mediacom Tbk. & Tinggi & Rendah \\
17 & MNC Investama Tbk. & Rendah & Rendah \\
\hline
\end{tabular}

\section{SIMPULAN}

Pasar modal mempunyai peranan yang cukup besar sebagai salah satu sumber pembiayaan bagi dunia usaha, disisi lain juga merupakan tempat investasi bagi masyarakat termasuk pemodal kecil dan menengah. Pasar modal memiliki peran penting bagi perekonomian suatu negara yang sedang berkembang seperti bangsa Indonesia, terutama dalam proses alokasi dana dari pihak yang memiliki surplus dana (investor) kepada pihak yang memerlukan dana (perusahaan). Kehadiran pasar modal di Indonesia semakin memberikan kesempatan luas bagi perusahaan untuk memperoleh dana dari masyarakat. Dalam hal ini, istilah multinasional menunjukan pada perusahaan penanaman modal asing (PMA), sebagai anak perusahaan yang berafiliasi bisnis dengan dengan perusahaan induk yang berkedudukan kantor pusat diluar negeri. Sedangkan, perusahaan domestik adalah perusahaan penanaman modal dalam negeri , kantor pusat yang berkedudukan di Indonesia.

Perusahaan PMA dengan profitabiltas dan likuiditas yang tinggi terdapat 1 (satu) perusahaan yaitu United tracktor hal ini ditunjukan dengan nilai earning per share (EPS) sebesar 1.440 per lembar saham. EPS yang tinggi akan menarik minat para Investor untuk menanamkan dananya lebih banyak, dan keuntungan perusahaan adalah mendapatkan dana segar untuk lebih meningkatkan produktivitas perusahaan. Dan likuiditas sebesar $206 \%$ pada Current rasio, $158 \%$ pada Quick test ratio, dan cash ratio $62 \%$. 


\section{Daftar Pustaka}

Alijoyo, F. Antonius. 2003. Rasio Keuangan dan Praktek Corporate Governance. http://www.fcgi.or.id.g/rasio/keuangan14-08-2002

Belkoui \& Riahi, Ahmed. 2000. Accounting theory, $4^{\text {th }}$ Edition. Thomson.

Brigham, Gapenski, Daves. 1999. Intermediate Financial Management. Sixth Edition. USA: The Dryden Press Harcourt Brace College Publisher.

Cahan, S.F. 1992. The Effect A Antitrust Investigations on Discretionary Accruals A Refined Test of the Political Cost Hipotesis. The Accounting Review. Vol. 67 No. 1. January, hal. 77-95.

Cornett M. M, J. Marcuss, Saunders dan Tehranian H. 2006. Earnings Management, Corporate Governance, and True Financial Performance. http://papers.ssrn.com/

Eisenhardt, Kathleem. M. 1989. Agency Theory: An Assesment and Review. Academy of management Review, 14, hal 57-74.

Fisher, Marilyn, \& Rosenzweigh, Kenneth. 1995. Attitudes of Students and accounting Practitioners Concerning the Ethical Acceptability of Earnings Management. Journal of Business Ethics, Volume 14, hal. 443-444.

Fuad. 2005. Simultanitas Dan "Trade-Off" Pengambilan Keputusan Finansial Dalam Mengurangi Konflik Agensi: Peran Dari Corporate Ownership. Simposium Nasional Akuntansi VIII, IAI.

Gitman, lawrance.J. 2003. Principle Of Management Finance, Ten Edition, United State: Pearson Education, Inc.

Gitman, Lawrence J. 2003. Principle of Managerial Finance. The Addison of Wesley Series in Finance International Edition.

Jensen, Michael C. \& W.H. Meckling. 1976. Theory of The Firm: Managerial Behavior, Agency Cost and Ownership Structure. Journal of Financial Economics 3. hal. 305360.

Keown, J Arthur., David F. Scott., John D. Marthin, \& Willian Petty. 1999. Basic Financial Management. USA: Prentice Hall International Editions.

Lilis Setiawati. 2001. Rekayasa Akrual untuk Meminimalkan Pajak. Simposium Nasional Akuntansi V, IAI.

Porter, Michael E. 1999. Competitive Advance: Creating and Sustaining Superior Performance. USA: Three Free Press.

Raharjo, Budi. 2007. keuangan dan Akuntansi, Edisi Pertama, Cetakan pertama. Yogyakarta: Graha Ilmu.

Riyanto, Bambang. 2008. Dasar-dasar pembelajaran perusahaan. Yogyakarta: BPFE.

Sawir, Agnes . 2009. Analisa Kinerja Keuangan Dan Perencanaan Keuangan Perusahaan. Jakarta: PT Gramedia Pustaka Utama

Syafri, Harahap Sofyan. 2008. Analisa Kritis Atas Laporan Keuangan. Jakarta: PT Raja Grafindo Persada. 